\title{
Epistasis, physical capacity-related genes and exceptional longevity: FNDC5 gene interactions with candidate genes FOXOA3 and $A P O E$
}

Noriyuki Fuku ${ }^{1 *}{ }^{*}$, Roberto Díaz-Peña ${ }^{2,3{ }^{\dagger}}$, Yasumichi Arai ${ }^{4}$, Yukiko Abe ${ }^{4}$, Hirofumi Zempo ${ }^{1}$, Hisashi Naito ${ }^{1}$, Haruka Murakami ${ }^{5}$, Motohiko Miyachi ${ }^{5}$, Carlos Spuch ${ }^{6}$, José A. Serra-Rexach ${ }^{8}$, Enzo Emanuele ${ }^{7}$,

Nobuyoshi Hirose ${ }^{1}$ and Alejandro Lucia ${ }^{9}$

From 34th FIMS World Sports Medicine Congress

Ljubljana, Slovenia. $29^{\text {th }}$ September $-2^{\text {nd }}$ October 2016

\begin{abstract}
Background: Forkhead box O3A (FOXOA3) and apolipoprotein E (APOE) are arguably the strongest gene candidates to influence human exceptional longevity (EL, i.e., being a centenarian), but inconsistency exists among cohorts. Epistasis, defined as the effect of one locus being dependent on the presence of 'modifier genes', may contribute to explain the missing heritability of complex phenotypes such as EL. We assessed the potential association of epistasis among candidate polymorphisms related to physical capacity, as well as antioxidant defense and cardiometabolic traits, and EL in the Japanese population. A total of 1565 individuals were studied, subdivided into 822 middle-aged controls and 743 centenarians.

Results: We found a FOXOA3 rs2802292 T-allele-dependent association of fibronectin type III domain-containing 5 (FDNC5) rs 16835198 with EL: the frequency of carriers of the FOXOA3 rs2802292 T-allele among individuals with the rs16835198 GG genotype was significantly higher in cases than in controls $(P<0.05)$. On the other hand, among noncarriers of the APOE 'risk' $\varepsilon 4$-allele, the frequency of the FDNC5 rs16835198 G-allele was higher in cases than in controls ( $48.4 \%$ vs. $43.6 \%, P<0.05$ ). Among carriers of the 'non-risk' APOE $\varepsilon 2$-allele, the frequency of the rs $16835198 \mathrm{G}$-allele was higher in cases than in controls ( $49 \%$ vs. $37.3 \%, P<0.05$ ).
\end{abstract}

Conclusions: The association of FDNC5 rs16835198 with EL seems to depend on the presence of the FOXOA3 rs2802292 T-allele and we report a novel association between FNDC5 rs 16835198 stratified by the presence of the APOE ع2/ع4-allele and EL. More research on 'gene* $g e n e^{\prime}$ and 'gene*environment' effects is needed in the field of EL.

Keywords: Exceptional longevity, Centenarians, FOXO3A, FNDC5, APOE, Ageing

\footnotetext{
* Correspondence: noriyuki.fuku@nifty.com

${ }^{\dagger}$ Equal contributors

${ }^{1}$ Graduate School of Health and Sports Science, Juntendo University, Chiba,

Japan

Full list of author information is available at the end of the article
} 


\section{Background}

Exceptional longevity (EL), defined as reaching 100+ years of age, is a generally accepted model of healthy aging with major age-related diseases usually delayed [1], and sometimes even avoided, in centenarians [2]. Age at death during adulthood has a heritability of $\sim 25 \%$ [3] and consequently EL is likely to be, at least in part, a heritable phenotype. However, genome wide association studies (GWAS) of individuals with EL have mostly yielded poor results, with single nucleotide polymorphisms (SNPs) in the apolipoprotein $\mathrm{E}(A P O E)$ and/or forkhead box O3A (FOXOA3) genes being usually the only variants achieving genome-wide significance [3], although there is no unanimity for FOXOA3 [4]. The $A P O E$ \&4-allele, which is linked to a higher risk of cardiovascular and Alzheimer's disease [5, 6], is associated with a lower likelihood of reaching EL, whereas the $\varepsilon 2$ allele seems to show a positive association with EL and is more frequently found in centenarians than in younger controls [7]. Nonetheless, the aforementioned associations can vary by population [7]. Similarly, there is evidence that genetic polymorphisms in the FOXO3A gene can be associated with EL, especially the rs2802292 SNP [8-12], but such an association has not been corroborated in some cohorts $[13,14]$. On the other hand, aging is inevitably associated with a decline physical function, especially in muscle mass and function (i.e., sarcopenia), with an acceleration of this process increasing the risk of mortality [15]. As such, there is a rationale for postulating the potential influence on EL of several variations in genes that are candidates to influence physical capacity and muscle function; however, up to date such candidate genes [e.g., $\alpha$-actinin-3 (ACTN3), thyrotropin-releasing hormone (TRHR) or acyl-CoA synthetase long-chain family member 1 (ACSL1)], have not shown individual associations with EL [16, 17].

Epistasis, defined as the effect of one locus on a given phenotype being dependent on the presence of one or more 'modifier genes', may contribute to explain the missing heritability of complex phenotypes [18]. Though research on the role of epistasis in EL has been rather limited in the past [19], evidence for an impact of genetic interactions in determining human longevity is quickly growing. For instance, longevity may be partly determined by epistatic interactions involving mitochondrial DNA (mtDNA) loci [20]. Also, a combination of functional SNPs within adenosine deaminase $(A D A)$ and tumor necrosis factor alpha $(T N F-\alpha)$ genes can influence life-expectancy in a gender-specific manner [21]. More recently, Tan et al. reported that interactions of SNPs in the FOXO gene family influences longevity [22]. To our knowledge, only two studies have included the $A P O E$ gene for evaluating gene $\mathrm{x}$ gene effects on longevity [23, 24]. Jazwinski et al. reported that the GTPase HRAS (also known as transforming protein p21, HRAS1) and ceramide synthase 1 (also known as LAG1, longevity assurance homolog, LASS1) genes interact with the APOE gene to reduce age-related increases in lipotoxic events, and haplotypes conformed by the two genes are associated with EL [23]. In the other study, epistasis analysis was performed between $A P O E$ haplotypes and haptoglobulin gene $(H P)$ functional polymorphisms, with $H P{ }^{*} 1 /{ }^{*} 1$ genotype protecting $A P O E$ \&4-carriers from age-related negative selection; in light of these results, the authors called for further research on $A P O E / H P$ interactions in age-related diseases such as Alzheimer's and Parkinson's disease [24].

Japan has the longest life expectancy in the world, as well as the highest number of individuals reaching EL [25]. Thus, Japanese long-lived people represent an attractive model to study potential genetic contributors to EL. The purpose of the present study was to assess whether the interaction between variants in genes that are candidates to influence physical capacity and energy metabolism [ACTN3, TRHR, ACSL1], interact with APOE and $F O X O 3 A$ genes, and potentially associate with EL in the Japanese population. We also studied the potential interaction with candidate genes involved in antioxidant defense [glutathione peroxidase 1 (GPX1), superoxide dismutase $2(S O D 2)]$ and cardiometabolic traits [fibronectin type III domain-containing 5 (FNDC5), cyclin-dependent kinase inhibitor $2 \mathrm{~B}$ antisense noncoding RNA (CDKN2B-AS1)],

\section{Results}

The observed genotypic distributions of SNPs were consistent with Hardy-Weinberg Equilibrium (HWE) expectations both in controls and centenarians $(P>0.05)$. Table 1 shows the single marker allelic association results of the 12 SNPs included in the study. The frequency of the $A P O E$ \&2-allele was higher in cases than in controls, whereas $\varepsilon 4$-allele frequency was lower in the former (all $P<0.01$ ), as shown previously by us using part of the present cohort [26]. None of the other SNPs, including FOXOA3 rs2802292, was associated with EL, and genotypes did not differ significantly between cases and controls in the recessive, dominant or additive models (all $P>0.05$ ) (data not shown). No significant differences were observed in sex-based analyses (data not shown).

With regards to epistasis, we found a FOXOA3 rs2802292 T-allele-dependent association of fibronectin type III domain-containing 5 (FDNC5) rs16835198 with $\mathrm{EL}$, that is, among individuals with the rs16835198 GG genotype, the frequency of carriers of the FOXOA3 rs2802292 T-allele was significantly higher in cases than in controls $(P<0.05$; Table 2$)$. On the other hand, among non-carriers of the $A P O E$ 'risk' $\varepsilon 4$-allele, the frequency of the FDNC5 rs16835198 G-allele was higher in 
Table 1 Single marker allelic association results of the 12 genetic variants included in the study

\begin{tabular}{|c|c|c|c|c|c|c|c|c|c|c|}
\hline \multirow[t]{2}{*}{ Chromosome } & \multirow[t]{2}{*}{ SNP } & \multirow[t]{2}{*}{ Gene } & \multirow[t]{2}{*}{ Position } & \multirow{2}{*}{$\begin{array}{l}\text { Minor allele } \\
\text { nucleotide }\end{array}$} & \multicolumn{2}{|c|}{ Minor allele frequency } & \multirow[t]{2}{*}{$\mathrm{P}_{\mathrm{BONF}}$} & \multirow[t]{2}{*}{ OR } & \multirow{2}{*}{$\begin{array}{l}\text { lower } \\
95 \% \mathrm{Cl}\end{array}$} & \multirow{2}{*}{$\begin{array}{l}\text { Upper } \\
95 \% \mathrm{Cl}\end{array}$} \\
\hline & & & & & Centenarians & Controls & & & & \\
\hline 1 & rs16835198 & FNDC5 & $32,861,080$ & G & 0.48 & 0.45 & 0.488 & 1.16 & 1.00 & 1.33 \\
\hline 2 & rs1050450 & GPX1 & $49,357,401$ & $\mathrm{~T}$ & 0.08 & 0.08 & 1 & 0.95 & 0.73 & 1.25 \\
\hline 4 & rs6552828 & ASCL1 & $1.85 E+08$ & G & 0.40 & 0.41 & 1 & 0.95 & 0.82 & 1.10 \\
\hline 6 & rs4880 & SOD2 & $1.6 \mathrm{E}+08$ & G & 0.13 & 0.14 & 1 & 0.94 & 0.77 & 1.16 \\
\hline 8 & rs7832552 & TRHR & $1.09 \mathrm{E}+08$ & $\mathrm{~T}$ & 0.50 & 0.50 & 1 & 0.97 & 0.85 & 1.12 \\
\hline 8 & rs7460 & PTK2 & $1.41 E+08$ & $\mathrm{~T}$ & 0.36 & 0.36 & 1 & 1.00 & 0.860 & 1.15 \\
\hline 8 & rs7843014 & PTK2 & $1.41 E+08$ & A & 0.25 & 0.27 & 1 & 0.88 & 0.75 & 1.04 \\
\hline 9 & rs1333049 & CDKN2B-AS1 & $22,125,504$ & $\mathrm{C}$ & 0.47 & 0.46 & 1 & 1.05 & 0.91 & 1.21 \\
\hline 9 & rs2802292 & FОXОЗ & $108,587,315$ & G & 0.29 & 0.28 & 1 & 1.05 & 0.90 & 1.23 \\
\hline 11 & rs1815739 & ACTN3 & $66,560,624$ & $C$ & 0.46 & 0.47 & 1 & 0.96 & 0.84 & 1.11 \\
\hline 19 & rs429358 & $A P O E$ & $44,908,684$ & $C$ & 0.05 & 0.11 & $6.19 \times 10^{-10}$ & 0.39 & 0.29 & 0.52 \\
\hline 19 & rs7412 & $A P O E$ & $44,908,882$ & $\mathrm{~T}$ & 0.07 & 0.04 & 0.002 & 1.80 & 1.32 & 2.46 \\
\hline
\end{tabular}

Allele frequencies were compared using chi-square statistics; ORs and $95 \%$ confidence interval (95\% Cl) were calculated using Plink software Abbreviations: $95 \% \mathrm{Cl} 95 \%$ confidence interval, $O R$ odds ratio, $P_{B O N F} P$-value after Bonferroni correction, $S N P$ single nucleotide polymorphism

cases than in controls ( $48.4 \%$ vs. $43.6 \%, P<0.05$; Table 3$)$. In turn, among carriers of the 'non-risk' $A P O E$ e2-allele, the frequency of the rs 16835198 G-allele was higher in cases than in controls ( $49 \%$ vs. $37.3 \%, P<0.05)$. No other significant gene interaction was found to be associated with EL.

\section{Discussion}

Excluding $A P O E$, the present findings do not show replicable association of individual candidate genes, included those related to physical capacity and muscle function, with EL. However, we also assessed the effects of interactions among candidate polymorphisms on the one hand, and EL, on the other hand. In this regard, we report an association of FDNC5 rs16835198 with EL that seems to depend on the presence of the FOXOA3 rs2802292 T-allele. Moreover, we found a novel association between FNDC5 rs16835198 stratified by the presence of the APOE $\varepsilon 2 / \varepsilon 4$-allele, and EL. We believe this is an interesting finding because FNDC5 gene encodes the precursor of irisin which, although there is controversy [27], was recently identified a myokine -that is, a molecule released by muscles [28]. Irisin induces expression of uncoupling protein 1 and other brown adipose tissueassociated genes [partly via increased peroxisome proliferators-activated receptor $\alpha$ (PPAR- $\alpha)$ ] in white adipocytes, and thus increases thermogenesis and switching of these cells towards a brown fat-like phenotype [28]. In fact irisin has been postulated as a therapeutic agent against cardiometabolic disorders and a major component of the 'exercise polypill' [29].

Several mechanisms may link genetic variations in FOXO3A and FNDC5 genes with EL. For example, dysregulation of the nutrient-sensing somatotropic axis [comprising growth hormone and its secondary mediator, insulin-like growth factor-1 (IGF-1)] is a major hallmark of human aging [30]. IGF-1 and insulin signaling collectively represent the "insulin and IGF-1 signaling" pathway. Among the multiple targets of this pathway is the FOXO family of transcription factors, which are also involved in aging and show striking evolutionary conservation [31]. High serum irisin levels may contribute to successful aging, with circulating levels of this biomarker being in fact significantly higher in disease-free centenarians than in young healthy controls and being particularly higher than in young patients with acute

Table 2 Genotypic frequency distribution of FNDC5 rs16835198 according to the FDNC5 rs16835198 T-allele presence

\begin{tabular}{|c|c|c|c|c|}
\hline \multirow[t]{2}{*}{$\begin{array}{l}\text { FDNC5 (rs16835198) } \\
\text { Genotype }\end{array}$} & \multicolumn{2}{|l|}{$\begin{array}{l}\text { FOXO3A Presence of } \\
\text { rs } 2802292 \text { T-allele }\end{array}$} & \multirow[t]{2}{*}{$P$-value } & \multirow[t]{2}{*}{ OR $(95 \% \mathrm{Cl})$} \\
\hline & Controls $(n=754)$ & Centenarians $(n=668)$ & & \\
\hline$\overline{\mathrm{GG}}$ & $147(19.5 \%)$ & $162(24.3 \%)$ & 0.035 & $1.32(1.03-1.70)$ \\
\hline GT & $378(50.1 \%)$ & $323(48.3 \%)$ & NS & - \\
\hline$\pi$ & $229(30.4 \%)$ & $183(27.4 \%)$ & NS & - \\
\hline
\end{tabular}


Table 3 Allele frequency distribution of FNDC5 rs16835198 alleles according to APOE $\varepsilon 2 / \varepsilon 4$ status in the study population

\begin{tabular}{|c|c|c|c|c|c|}
\hline \multicolumn{2}{|l|}{$\begin{array}{l}\text { FNDC5 (rs16835198) } \\
\text { allele }\end{array}$} & \multicolumn{2}{|c|}{ Absence of $A P O E$ ع4-allele ${ }^{a}$} & \multicolumn{2}{|c|}{ Presence of APOE $\varepsilon 4$-allele ${ }^{a}$} \\
\hline & & Controls $(2 n=1306)$ & Centenarians $(2 \mathrm{n}=1340)$ & Controls $(2 n=336)$ & Centenarians $(2 n=128)$ \\
\hline \multirow[t]{4}{*}{ G } & N & 570 & 648 & 165 & 62 \\
\hline & $\%$ & $43.6 \%$ & $48.4 \%$ & $49.1 \%$ & $48.4 \%$ \\
\hline & $P$-value & 0.0167 & & NS & \\
\hline & OR $(95 \% \mathrm{Cl})$ & $1.21(1.04,1.41)$ & & - & \\
\hline \multirow[t]{4}{*}{$\mathrm{T}$} & N & 736 & 692 & 171 & 66 \\
\hline & $\%$ & $56.4 \%$ & $51.6 \%$ & $50.9 \%$ & $51.6 \%$ \\
\hline & $P$-value & 0.0167 & & NS & \\
\hline & OR $(95 \% \mathrm{Cl})$ & $0.83(0.71-0.96)$ & & - & \\
\hline \multirow{2}{*}{$\begin{array}{l}\text { FNDC5 (rs16835198) } \\
\text { allele }\end{array}$} & & \multicolumn{2}{|c|}{ Absence of APOE ع2-allele ${ }^{a}$} & \multicolumn{2}{|c|}{ Presence of APOE $\varepsilon 2$-allele ${ }^{a}$} \\
\hline & & Controls $(2 n=1508)$ & Centenarians $(2 \mathrm{n}=1258)$ & Controls $(2 n=134)$ & Centenarians $(2 n=210)$ \\
\hline \multirow[t]{4}{*}{ G } & $\mathrm{n}$ & 685 & 607 & 50 & 103 \\
\hline & $\%$ & $45.4 \%$ & $48.3 \%$ & $37.3 \%$ & $49 \%$ \\
\hline & $P$-value & NS & & 0.035 & \\
\hline & OR $(95 \% \mathrm{Cl})$ & - & & $1.62(1.04-2.52)$ & \\
\hline \multirow[t]{4}{*}{ T } & $n$ & 823 & 651 & 84 & 107 \\
\hline & $\%$ & $54.6 \%$ & $51.7 \%$ & $62.7 \%$ & $51 \%$ \\
\hline & $P$-value & NS & & 0.035 & \\
\hline & OR $(95 \% \mathrm{Cl})$ & - & & $0.62(0.40-0.96)$ & \\
\hline
\end{tabular}

Abbreviations: $95 \% \mathrm{Cl} 95 \%$ confidence interval, NS not significant, OR odds ratio

${ }^{a}$ All individuals underwent genotyping for rs429358 and rs7412. The 3 major isoforms of human APOE gene (E2, E3, and E4) coded by 3 alleles ( $\varepsilon 2$, $\varepsilon 3$, and $\varepsilon 4$ ) differ in amino acid sequence at 2 sites, residue 112 (rs429358) and residue 158 (rs7412)

myocardial infarction [32]. Moreover, genetic variants in the FNDC5 gene have been associated with in vivo insulin sensitivity [33], and aging is associated with alterations in insulin sensitivity/signaling [34]. Irisin might also play a significant role in reducing the risk of obesity or several related diseases [35]. In a previous report, we found no significant association between genotype and allele frequencies of polymorphisms in FNDC5 and EL [36]. However, the rs16835198 G-allele was associated with a trend towards lower luciferase gene repoter activity in vitro [36].

Insulin sensitivity could be a link explaining the association of the combination of the two loci in FOXO3A and FNDC5, as well as in APOE and FNDC5, with EL. Insulin metabolism as well as insulin-altering therapies in Alzheimer's disease are modulated by $A P O E$ status $[37,38]$, while irisin reduces diet-induced obesity and insulin resistance in vivo [28]. The FNDC5 rs16835198 Gallele could favor longevity in combination with the $A P O E$ \&2-variant, contributing to situations in which rs16835198 SNP distribution is found among long-lived subjects in proportions similar to those found in younger controls. Thus, the conditional effects of genes on the phenotype of aging could play a role in longevity. Most studies show a lower frequency of the $A P O E \varepsilon 4$ allele in centenarians than in younger controls, while the
$A P O E$ \&2-allele might be more frequent in centenarians than in younger controls [7]. A "gene $x$ gene" interaction would introduce a modifying allele in another locus, changing the impact of the risk/protective allele from deleterious to beneficial, or vice versa. Here, we report a significant effect of the rs16835198-G allele in the FNDC5 gene on the association between APOE $\varepsilon 2$ carriage/non-carriage and EL. There are some limitations in our study. First, our results should be ideally replicated in one or more ethnically and geographically-independent cohorts to account for potential differences in 'gene $\mathrm{x}$ environment' interactions. Another drawback of case: control designs as the present one is the choice of an appropriate control group, with demographic factors, notably differences in year of birth between centenarians and controls, being potential confounders (e.g., the centenarians and controls of our study were born in the early 1900s and after 1930, respectively) [39]. Differences in gender distribution between cases and controls are also to be accounted for because genetic factors influence survival at advanced age in a sex-specific manner [40]. In this regard, the potential demographic biases of cross-sectional comparisons of genotype/allele frequencies between controls and long lived individuals could be overcome by adding more complete demographic information to genetic data, 
allowing for estimation of survival rates related to candidate genes [40-42]. Because we have only analyzed one SNP within the FOXO3A and FNDC5 genes, further research with different variants of this or other genes involved in insulin-IGF-1, and insulin signaling collectively representing the "insulin and IGF-1 signaling" pathway, must be undertaken. On the other hand, the need for using independent populations for replication may generate some controversy. Some variants may have opposing consequences on the phenotype of interest, and the effect of gene $\mathrm{x}$ gene interactions on human health and lifespan might depend on several factors (e.g., internal and external exposure, including medication or different genetic backgrounds of individuals comprising the populations).

\section{Conclusion}

We found an association between FDNC5 rs16835198 stratified by the presence of the FOXOA3 rs2802292 Tallele, and EL, as well as between FNDC5 rs16835198 stratified by the presence of the APOE alleles, and EL. Our results suggest the need for further investigation on the possible influence of FOXO3A/FNDC5 interactions and $A P O E / F N D C 5$ interactions with EL, but also with other age-related diseases such as atherosclerosis, Alzheimer's, or Parkinson's disease. Moreover, identification of gene $\mathrm{x}$ gene and gene $\mathrm{x}$ environmental factors effects on lifespan may significantly improve our understanding of the association between genetic and non-genetic regulators of aging.

\section{Methods}

\section{Study population}

A total of 1565 individuals were recruited: 822 controls (aged 23-65 years; 604 women, 218 men) and 743 cases (centenarians aged 100-115 years; 623 women, 1120 men). The controls were enrolled from the Nutrition and EXercise Intervention Study (NEXIS) registered on ClinicalTrials.gov (Identifier: NCT 00926744). Inclusion criteria for the control group were being a man or woman aged 23-65 years with no history of stroke, cardiovascular disease, chronic renal failure, or walking difficulties related to knee or back pain [43]. Cases were collected from two cohorts that have been described in detail elsewhere [44]: the Tokyo Centenarians Study (TCS) and the Semi-Supercentenarians Study in Japan (SSC-J). The prevalence rates of hypertension, coronary artery disease and dementia in the Japanese centenarians were $63.6,28.8$ and 59.4\%, respectively [26].

\section{Genotyping}

Total DNA was extracted from venous blood with the QIAamp DNA Blood Maxi Kit (Qiagen, Hilden, Germany). SNP genotyping was performed using the following TaqMan ${ }^{\circ}$ genotyping assays (Applied Biosystems,
Foster City, CA): C_34204885_10 for rs16835198, Custom TaMan ${ }^{\circ}$ Assay for rs1050450, C_30469648_10 for rs6552828, C__8709053_10 for rs4880, C_29085798_10 for rs7832552, C_ 243385_10 for rs7460, C_11605645_10 for rs7843014, C__1754666_10 for rs1333049, C__1841568_10 for rs2802292, C_ 590 093_1 for rs1815739, C__904973_10 for rs7412 and C__3084793_20 for rs429358. Several quality control procedures, such as repeating the genotyping on a random $10 \%$ of the samples were carried out to assure no discrepant results in samples.

\section{Statistical analysis}

Statistical analysis of high-density SNP genotyping data was carried out as follows: allele frequencies in cases and controls were compared using chi-square statistics, and odds ratios (OR) and 95\% confidence intervals (95\% CI) were calculated using Plink software [45]. Bonferroni correction was applied by dividing the $P$-value by the number of SNPs tested to give the corrected $P$-value. Allele frequencies obtained for each SNP were tested for deviations from HWE expectations. The combined effects of $A P O E$ and FOXO3A alleles and SNPs studied on the risk of EL were analyzed by binary logistic regression with SPSS v.22 statistical software (IBM, Somers, NY, USA) and OR and $P$ values were calculated.

\section{Abbreviations \\ ACSL1: Acyl-CoA synthetase long-chain family member 1; ACTN3: Actinin-3; ADA: Adenosine deaminase; APOE: Apolipoprotein E; CDKN2B-AS1: Cyclin- dependent kinase inhibitor $2 B$ antisense noncoding RNA; EL: Exceptional longevity; FNDC5: Fibronectin type III domain-containing 5; \\ FOXOA3: Forkhead box O3A; GPX1: Glutathione peroxidase 1; GWAS: Genome wide association studies; HP: Haptoglobulin gene; HWE: Hardy-Weinberg Equilibrium; IGF-1: Insulin-like growth factor-1; mtDNA: Mitochondrial DNA; NEXIS: Nutrition and EXercise Intervention Study; OR: Odds ratios; SNPs: Single nucleotide polymorphisms; \\ SOD2: Superoxide dismutase 2; SSC-J: Semi-Supercentenarians Study in Japan; TCS: Tokyo Centenarians Study; TNF-a: Tumor necrosis factor alpha; TRHR: Thyrotropin-releasing hormone}

\section{Acknowledgements}

The authors acknowledge Dr. Kenneth McCreath for his editorial work.

Funding

Publication of this article is supported by grants from the Grant-in-Aid for Scientific Research (B) (15H03081 to N.F.) and Challenging Exploratory Research (16 K13052 to N.F.) programs of the Ministry of Education, Culture, Sports, Science and by a Grant-in-Aid for Scientific Research from the Ministry of Health, Labor, and Welfare of Japan (to M. M). Research by A. Lucia is supported by grants from the Spanish Ministry of Economy and Competitiveness and [Fondo de Investigaciones Sanitarias (FIS)] and Fondos Feder (grant number PI15/00558).

\section{Availability of data and materials}

All data generated and/or analyzed during this study are included in this published article.

\section{About this supplement}

This article has been published as part of BMC Genomics Volume 18 Supplement 8, 2017: Proceedings of the 34th FIMS World Sports Medicine Congress. The full contents of the supplement are available online at https:// bmcgenomics.biomedcentral.com/articles/supplements/volume-18-

supplement-8. 


\section{Authors' contributions}

All authors were involved in drafting the article or revising it critically for important intellectual content, and all authors approved the final version to be published. Study conception and design. DPR, FN and LA. Acquisition of data. Arai Y, Abe Y, ZH, Naito H, MH, MM and Hirose N. Analysis and interpretation of data. DPR, SRJA, SC and EE.

\section{Ethics approval and consent to participate}

The Ethics Committees of the Keio University and National Institute of Health and Nutrition approved this study and all subjects gave their written informed consent.

\section{Consent for publication}

Not applicable.

\section{Competing interests}

The authors declare that they have no competing interests.

\section{Publisher's Note}

Springer Nature remains neutral with regard to jurisdictional claims in published maps and institutional affiliations.

\section{Author details}

${ }^{1}$ Graduate School of Health and Sports Science, Juntendo University, Chiba, Japan. ${ }^{2}$ Hospital Universitari Institut Pere Mata, IISPV, URV. CIBERSAM, Reus, Spain. ${ }^{3}$ Facultad de Ciencias de la Salud, Universidad Autónoma de Chile, Talca, Chile. ${ }^{4}$ Center for Supercentenarian Medical Research, Keio University School of Medicine, Tokyo, Japan. ${ }^{5}$ Department of Physical Activity Research; National Institutes of Biomedical Innovation, Health and Nutrition, Tokyo, Japan. ${ }^{6}$ Neurology Group, Galicia Sur Health Research Institute (IIS Galicia Sur), Centro de investigación biomédica en red del área de salud mental (CIBERSAM), Vigo, Spain. ${ }^{7} 2$ E Science, Robbio, (PV), Italy. ${ }^{8}$ Centro de investigación biomédica en Envejecimiento y Fragilidad (CIBERFES), Madrid, Spain. ${ }^{9}$ European University and Research Institute i+12, Madrid, Spain.

\section{Published: 14 November 2017}

\section{References}

1. Soerensen M, Nygaard M, Debrabant B, Mengel-From J, Dato S, Thinggaard $\mathrm{M}$, et al. No association between variation in longevity candidate genes and aging-related phenotypes in oldest-old Danes. Exp Gerontol. 2016;78:57-61. [cited 2016 Nov 5] Available from: http://www.ncbi.nlm.nih.gov/pubmed/ 26946122

2. Terry DF, Sebastiani P, Andersen SL, Perls TT. Disentangling the roles of disability and morbidity in survival to exceptional old age. Arch Intern Med. 2008;168:277-83. Available from: http://www.pubmedcentral.nih.gov/ articlerender.fcgi?artid=2895331\&tool=pmcentrez\&rendertype=abstract

3. Brooks-Wilson AR. Genetics of healthy aging and longevity. Hum Genet. 2013;132:1323-38.

4. Sebastiani P, Gurinovich A, Bae H, Andersen S, Malovini A, Atzmon G, et al. Four Genome-Wide Association Studies Identify New Extreme Longevity Variants. J Gerontol A. 2017;72:1453-64. Available from: https://academic. oup.com/biomedgerontology/article/3072309/Four.

5. Kumar NT, Liestol K, Loberg EM, Reims HM, Brorson SH, Maehlen J. The apolipoprotein E polymorphism and cardiovascular diseases-an autopsy study. Cardiovasc Pathol. 2012;21:461-9. Available from: http://www.ncbi. nlm.nih.gov/pubmed/22440829

6. Liu C-C, Liu C-C, Kanekiyo T, Xu H, Bu G. Apolipoprotein E and Alzheimer disease: risk, mechanisms and therapy. Nat Rev Neurol. 2013;9:106-18. Available from: https://doi.org/10.1038/nrneurol.2012.263

7. Garatachea N, Marín PJ, Santos-Lozano A, Sanchis-Gomar F, Emanuele E, Lucia A. The ApoE gene is related with exceptional longevity: a systematic review and meta-analysis. Rejuvenation Res. 2015;18:3-13. Available from: http://online.liebertpub.com/doi/abs/10.1089/rej.2014.1605, http://www.ncbi. nlm.nih.gov/pubmed/25385258.

8. Willcox BJ, Donlon T a, He Q, Chen R, Grove JS, Yano K, et al. FOXO3A genotype is strongly associated with human longevity. Proc Natl Acad Sci U S A. 2008;105:13987-92.

9. Anselmi CV, Malovini A, Roncarati R, Novelli V, Villa F, Condorelli G, et al. Association of the FOXO3A locus with extreme longevity in a southern Italian centenarian study. Rejuvenation Res. 2009;12:95-104. Available from: http://online.liebertpub.com/doi/abs/10.1089/rej.2008.0827, http://www.ncbi. nlm.nih.gov/pubmed/19415983.

10. Li Y, Wang WJ, Cao H, Lu J, Wu C, Hu FY, et al. Genetic association of FOXO1A and FOXO3A with longevity trait in Han Chinese populations. Hum Mol Genet. 2009;18:4897-904.

11. Sun $L$, Hu C, Zheng C, Qian Y, Liang Q, Lv Z, et al. FOXO3 variants are beneficial for longevity in southern Chinese living in the Red River basin: a case-control study and meta-analysis. Sci Rep. 2015;5:9852. Available from: http:/www.nature.com/srep/2015/150408/srep09852/full/srep09852.html

12. Soerensen M, Dato S, Christensen K, McGue M, Stevnsner T, Bohr VA, et al. Replication of an association of variation in the FOXO3A gene with human longevity using both case-control and longitudinal data. Aging Cell. 2010;9:1010-7.

13. Flachsbart F, Caliebe A, Kleindorp R, Blanché $H$, von Eller-Eberstein $H$, Nikolaus $\mathrm{S}$, et al. Association of FOXO3A variation with human longevity confirmed in German centenarians. Proc Natl Acad Sci U S A. 2009;106:2700-5.

14. Fuku N, Díaz-Peña R, Arai Y, Abe Y, Pareja-Galeano H, Sanchis-Gomar F, et al. rs2802292 polymorphism in the FOXO3A gene and exceptional longevity in two ethnically distinct cohorts. Maturitas. 2016;92:110-4.

15. Fuku N, Alis R, Yvert T, Zempo H, Naito H, Abe $Y$, et al. Muscle-related polymorphisms (mstn rs1805086 and actn3 rs1815739) are not associated with exceptional longevity in Japanese centenarians. PLoS One. 2016;11:e0166605

16. Fuku N, He ZH, Sanchis-Gomar F, Pareja-Galeano H, Tian Y, Arai Y, et al. Exceptional longevity and muscle and fitness related genotypes: a functional in vitro analysis and case-control association replication study with SNPs THRH rs7832552, IL6 rs 1800795 and ACSL1 rs6552828. Front Aging Neurosci. 2015;7:59.

17. Garatachea N, Pareja-Galeano H, Sanchis-Gomar F, Santos-Lozano A, FiuzaLuces C, Morán M, et al. Exercise attenuates the major hallmarks of aging. Rejuvenation Res. 2015;18:57-89. Available from: http://onlineliebertpub. com/doi/abs/10.1089/rej.2014.1623

18. Cordell HJ. Epistasis: what it means, what it doesn't mean, and statistical methods to detect it in humans. Hum Mol Genet. 2002;11:2463-8. Available from: http://www.ncbi.nlm.nih.gov/pubmed/12351582

19. Ukraintseva S, Yashin A, Arbeev K, Kulminski A, Akushevich I, Wu D, et al. Puzzling role of genetic risk factors in human longevity: "risk alleles" as prolongevity variants. Biogerontology. 2016;17:109-27.

20. Niemi A-K, Moilanen JS, Tanaka M, Hervonen A, Hurme M, Lehtimäki T, et al. A combination of three common inherited mitochondrial DNA polymorphisms promotes longevity in Finnish and Japanese subjects. Eur J Hum Genet. 2005;13:166-70

21. Napolioni V, Carpi FM, Giannì P, Sacco R, Di Blasio L, Mignini F, et al. Ageand gender-specific epistasis between ADA and TNF-a influences human life-expectancy. Cytokine. 2011;56:481-8.

22. Tan Q, Soerensen M, Kruse TA, Christensen K, Christiansen L. A novel permutation test for case-only analysis identifies epistatic effects on human longevity in the FOXO gene family. Aging Cell. 2013;12:690-4.

23. Jazwinski SM, Kim S, Dai J, Li L, Bi X, Jiang JC, et al. HRAS1 and LASS1 with APOE are associated with human longevity and healthy aging. Aging Cell. 2010;9:698-708.

24. Napolioni V, Giannì P, Carpi FM, Predazzi IM, Lucarini N. APOE haplotypes are associated with human longevity in a Central Italy population: evidence for epistasis with HP 1/2 polymorphism. Clin Chim Acta. 2011;412:1821-4.

25. Santos-Lozano A, Sanchis-Gomar F, Pareja-Galeano H, Fiuza-Luces C, Emanuele E, Lucia A, et al. Where are supercentenarians located? A worldwide demographic study. Rejuvenation Res. 2015;18:14-9. Available from: http://www.ncbinlm.nih. gov/pubmed/25386976

26. Garatachea N, Emanuele E, Calero M, Fuku N, Arai Y, Abe Y, et al. ApoE gene and exceptional longevity: insights from three independent cohorts. Exp Gerontol. 2014;53:16-23.

27. Timmons JA, Baar K, Davidsen PK, Atherton PJ. Is irisin a human exercise gene? Nature. 2012;488:E9-10.

28. Boström P, Wu J, Jedrychowski MP, Korde A, Ye L, Lo JC, et al. A PGC1-adependent myokine that drives brown-fat-like development of white fat and thermogenesis. Nature. 2012;481:463-8. [cited 2016 Nov 9] Available from: http://www.pubmedcentral.nih.gov/articlerender.fcgi?artid=3522098\& tool=pmcentrez\&rendertype $=$ abstract

29. Fiuza-Luces C, Garatachea N, Berger NA, Lucia A. Exercise is the real Polypill. Physiology. 2013;28:330-58. Available from: http://physiologyonline. physiology.org/cgi/doi/10.1152/physiol.00019.2013 
30. López-Otín C, Galluzzi L, Freije JMP, Madeo F, Kroemer G. Metabolic control of longevity. Cell. 2016;166:802-21.

31. Kenyon CJ. The genetics of ageing. Nature. 2010;464:504-12.

32. Emanuele E, Minoretti P, Pareja-Galeano H, Sanchis-Gomar F, Garatachea N, Lucia A. Serum irisin levels, precocious myocardial infarction, and healthy exceptional longevity. Am J Med. 2014;127:888-90. Available from: http:// www.ncbi.nlm.nih.gov/pubmed/24813865.

33. Staiger H, Böhm A, Scheler M, Berti L, Machann J, Schick F, et al. Common genetic variation in the human FNDC5 locus, encoding the novel musclederived "Browning" factor Irisin, determines insulin sensitivity. PLoS One. 2013;8:e61903.

34. Barbieri M, Gambardella A, Paolisso G, Varricchio M. Metabolic aspects of the extreme longevity. Exp Gerontol. 2008;43:74-8.

35. Spiegelman BM. Banting lecture 2012: regulation of adipogenesis: toward new therapeutics for metabolic disease. Diabetes. 2013;62:1774-82.

36. Sanchis-Gomar F, Garatachea N, He ZH, Pareja-Galeano H, Fuku N, Tian Y, et al. FNDC5 (irisin) gene and exceptional longevity: a functional replication study with rs16835198 and rs726344 SNPs. Age (Dordr). 2014;36:9733.

37. Craft S, Asthana S, Schellenberg G, Baker L, Cherrier M, Boyt AA, et al. Insulin effects on glucose metabolism, memory, and plasma amyloid precursor protein in Alzheimer's disease differ according to apolipoprotein-E genotype. Ann N Y Acad Sci. 2000;903:222-8. Available from: http://www. ncbi.nlm.nih.gov/entrez/query.fcgi?db=pubmed\&cmd=Retrieve\&dopt= AbstractPlus\&list_uids $=10818510$

38. Aisen PS, Berg JD, Craft S, Peskind ER, Sano M, Teri L, et al. Steroid-induced elevation of glucose in Alzheimer's disease: relationship to gender, apolipoprotein E genotype and cognition. Psychoneuroendocrinology. 2003;28:113-20.

39. Lewis SJ. Methodological problems in genetic association studies of longevitythe apolipoprotein E gene as an example. Int J Epidemiol. 2004;33:962-70. [cited 2016 Nov 9]Available from: http://www.ncbi.nlm.nih.gov/pubmed/ 15319409

40. Passarino G, Montesanto A, Dato S, Giordano S, Domma F, Mari V, et al. Sex and age specificity of susceptibility genes modulating survival at old age. Hum Hered. 2006;62:213-20.

41. Yashin Al, De Benedictis G, Vaupel JW, Tan Q, Andreev KF, lachine IA, et al. Genes, demography, and life span: the contribution of demographic data in genetic studies on aging and longevity. Am J Hum Genet. 1999;65:1178-93. Available from: http://www.cell.com/article/S0002929707626214/fulltext

42. Dato S, Carotenuto L, Benedictis G. Genes and longevity: a genetic-demographic approach reveals sex- and age-specific gene effects not shown by the casecontrol approach (APOE and HSP70.1 loci). Biogerontology. 2007;8:31-41.

43. Murakami H, lemitsu M, Fuku N, Sanada K, Gando Y, Kawakami R, et al. The Q223R polymorphism in the leptin receptor associates with objectively measured light physical activity in free-living Japanese. Physiol Behav. 2014;129:199-204.

44. Gondo $Y$, Hirose N, Arai $Y$, Inagaki $H$, Masui $Y$, Yamamura $K$, et al. Functional status of centenarians in Tokyo, Japan: developing better phenotypes of exceptional longevity. J Gerontol A Biol Sci Med Sci. 2006;61:305-10. [cited 2016 Nov 4] Available from: http://www.ncbi.nlm.nih.gov/pubmed/16567382.

45. Purcell S, Neale B, Todd-Brown K, Thomas L, Ferreira MAR, Bender D, et al. PLINK: a tool set for whole-genome association and population-based linkage analyses. Am J Hum Genet. 2007;81:559-75.

\section{Submit your next manuscript to BioMed Central and we will help you at every step:}

- We accept pre-submission inquiries

- Our selector tool helps you to find the most relevant journal

- We provide round the clock customer support

- Convenient online submission

- Thorough peer review

- Inclusion in PubMed and all major indexing services

- Maximum visibility for your research

Submit your manuscript at www.biomedcentral.com/submit 